\title{
Pleural Adenomatoid Tumor
}

National Cancer Institute

\section{Source}

National Cancer Institute. Pleural Adenomatoid Tumor. NCI Thesaurus. Code C4499.

A rare benign neoplasm that arises from the mesothelial cells of the pleura. It is characterized by a proliferation of epithelioid cells forming glandular and tubular patterns in a fibrous stroma. 